\begin{tabular}{|c|c|c|}
\hline \multirow{2}{*}{\multicolumn{3}{|c|}{$\begin{array}{l}\text { ENTOMOLOGICA HUNGARICA } \\
\text { ROVARTANI KÖZLEMÉNYEK }\end{array}$}} \\
\hline & & \\
\hline Tolu & 2019 & pp. $247-271$ \\
\hline
\end{tabular}

\title{
New species and new records of Campopleginae from the Palaearctic region (Hymenoptera: Ichneumonidae)
}

\author{
Zoltán VAS \\ Hungarian Natural History Museum, Department of Zoology, \\ H-1088 Budapest, Barossutca 13, Hungary.E-mail:vas.zoltan@nhmus.hu
}

\begin{abstract}
Campoletis ensifera sp. n., Meloboris sagittaria sp. n. and Venturia atrata sp. n. are described from Mongolia. The hitherto unknown male of Leptoperilissus ibericus Horstmann, 1987 and of Casinaria camura Vas, 2019 are firstly described. First records of Alcima orbitale (Gravenhorst, 1829) from Republic of North Macedonia and Mongolia, Campoletis annulata (Gravenhorst, 1829), Campoletis crassicornis (Tschek, 1871), Campoletis dilatator (Thunberg, 1822), Campoletis ensator (Gravenhorst, 1829), Campoletis fuscipes (Holmgren, 1856), Campoletis latrator (Gravenhorst, 1829), Campoletis pectalis Riedel, 2017, Campoletis procera (Brischke, 1880), Campoletis varians (Thomson, 1887), and Campoletis viennensis (Gravenhorst, 1829) from Mongolia, Leptocampoplex cremastoides (Holmgren, 1860) from Kosovo and Republic of North Macedonia, Leptoperilissus ibericus Horstmann, 1987 from Algeria, Leptoperilissus maroccanus Horstmann, 1993 from Spain, Meloboris collector (Thunberg, 1822) from Armenia, Jordan, Kosovo and Serbia, Meloboris moldavica (Constantineanu et Mustata, 1972) from Mongolia, Hungary, Portugal and Turkmenistan, Phobocampe bicingulata (Gravenhorst, 1829) from Armenia, Phobocampe tempestiva (Holmgren, 1860) from Hungary and Switzerland, Porizon transfuga (Gravenhorst, 1829) from Bulgaria and Hungary, Pyracmon fumipennis (Zetterstedt, 1838) from Montenegro, Republic of North Macedonia and Slovakia, Rhimphoctona longicauda Horstmann, 1980 and Rhimphoctona megacephalus (Gravenhorst, 1829) from Romania, Rhimphoctona rufocoxalis (Clément, 1924) and Rhimphoctona teredo (Hartig, 1847) from Slovakia, and Venturia mongolica (Kokujev, 1915) from Mongolia are reported. With 3 figures.
\end{abstract}

Key words - Alcima, Campoletis, Casinaria, Leptocampoplex, Leptoperilissus, Meloboris, Phobocampe, Porizon, Pyracmon, Rhimphoctona, Venturia, Campoletis ensifera sp. n., Meloboris sagittaria sp. n., Venturia atrata sp. n., Leptoperilissus ibericus male, Casinaria camura male

\section{INTRODUCTION}

The ongoing identification process of Ichneumonidae material in the Hungarian Natural History Museum (HNHM, Budapest, Hungary) already yielded several faunistical and taxonomical results regarding the ichneumon 
wasp fauna of the Palaearctic region (see e.g. VAS 2013, 2015, VAS et al. 2015, VAs 2015, 2016a, b, $c, d$, e, VAs \& Kutasi 2016, VAs \& Schwarz 2018, VAs 2018, $2019 a, b, c, d)$. Recently revealed results, regarding the subfamily Campopleginae, are given in this paper: three new species, Campoletis ensifera sp. n., Meloboris sagittaria sp. n. and Venturia atrata sp. n. are described from Mongolia, the first description of the male sex of Leptoperilissus ibericus Horstmann, 1987 and that of Casinaria camura Vas, 2019 are provided, and 25 species are first reported from 16 countries of the Western and Eastern Palaearctic regions.

Ichneumonidae taxonomy and nomenclature follow YU \& HORSTMANN (1997) and YU et al. (2012). The morphological terminology follows GAULD (1991) and GAULD et al. (1997) in general; however, in some cases the corresponding terminology of Townes (1969) is also indicated. Taxa are listed alphabetically. All mentioned specimens are deposited in the Hymenoptera Collection of the HNHM.

Identifications were based on Ashmead (1906), KoKUJEv (1915), Perkins (1942), Uchida (1942, 1957), Momoi (1962, 1965), Townes (1970), Horstmann (1970), Constantineanu \& Mustata (1972), Kusigemati (1972a,b), Aubert (1974), Gupta \& MAHeShWARy (1977), Horstmann (1978, 1979, 1980), Kasparyan (1981), Barron \& Walley (1983), HorstmanN (1987, 1993), Kusigemati (1993), Jonathan (1999), Horstmann (2004), He et al. (2004), ŠEDIVÝ (2004), K HALAIM \& KASPARYAN (2007), HorSTMANN (2008), Riedel (2017), VARga (2017), VAS (2019a, d), and on checking the necessary type materials. The specimens were identified by the author using a Nikon SMZ645 stereoscopic microscope. Photos were taken with Nikon D5200 and Nikon AF Micro Nikkor 60mm lens and MitutoyoM Plan A po 5 X microscope lens. Exposures were stacked in ZereneStacker, post image work was done with ImageJ $1.52 \mathrm{c}$ and Photoshop CS5.

\section{RESULTS}

\section{Alcima orbitale (Gravenhorst, 1829)}

Material examined - Mongolia: Central aimak, Zuun-Chara, 1390m, 8.VII.1963, leg. Z. Kaszab (Nr. 98), 1 ㅇ. - Republic of North Macedonia [on label: Yugoslavia, Macedonia]: Lake Dojran, 150-500m, 9-10.V.1971, leg. J. Papp \& S. Horvatovich (Nr. 7), 1 . .

Remarks - First records for Mongolia and for Republic of North Macedonia. This species is widely distributed in the Palaearctic region (YU et al. 2012). 
Campoletis annulata (Gravenhorst, 1829)

Material examined - Mongolia: Central aimak, Ulan-Baator, Nucht in Bogdo ul, 1600-1750m, 10.VI.1966, leg. Z. Kaszab (Nr. 514), 10'; Central aimak, SO von Somon Bajanzogt, 1600m, 11.VI.1966, leg. Z. Kaszab (Nr. 519), 10; BajanÖlgij aimak, im Tal des Flusses Chavcalyn gol, $25 \mathrm{~km}$ O von Somon Cagannuur, 1850m, 3.VII.1968, leg. Z. Kaszab (Nr. 1056), 2 1 ${ }^{\text {T; }}$ Uvs aimak, Pass Ulaan davaa, am östl. Hang, zw. See Örög nuur und Ulaagom, 1950m, 6.VII.1968, leg. Z. Kaszab (Nr. 1069), 19; Zavchan aimak, Choit chunch, 26 km ONO von See Temen nuur, 2150m, 13.VII.1968, leg. Z. Kaszab (Nr. 1104), $10^{\lambda}$.

Remarks - First records for Mongolia. This species is widely distributed in the Palaearctic region (Yu et al. 2012, Riedel 2017, VAs 2019a).

Campoletis dilatator (Thunberg, 1822)

Material examined - Mongolia: Central aimak, SO von Somon Bajanzogt, 1600m, 27.VII.1966, leg. Z. Kaszab (Nr. 749), $10^{\text {त. }}$

Remarks - First record for Mongolia. This species is known from several countries of the Western Palaearctic region, and from Kyrgyzstan (YU et al. 2012, RIEDEL 2017); hence, the present record represents the easternmost locality of the distribution of this species.

\section{Campoletis crassicornis (Tschek, 1871)}

Material examined-Mongolia: Archangaj aimak, Changaj Gebirge, $8 \mathrm{~km} \mathrm{~W}$ von Somon Urdtamir, 1620m, 21.VII.1966, leg. Z. Kaszab (Nr. 724), 10; Central aimak, Toagoni ovoo, 6-10 km N von Ulan-Baator, 1700m, 4.VI.1968, leg. Z. Kaszab (Nr. 934), 10'; same locality, 7-8.VI.1968, leg. Z. Kaszab (Nr. 938), 1 ; Bajan-Ölgij aimak, NO Ecke des Sees Tolbo nuur, 2100m, 26.VII.1968, leg. Z. Kaszab (Nr. 1151), 4 .

Remarks - First records for Mongolia. This species is known from several countries of the Western Palaearctic region (YU et al. 2012, Riedel 2017, VAS 2019a); the present records represent the first report of this species from the Eastern Palaearctic region.

\section{Campoletis ensator (Gravenhorst, 1829)}

Materialexamined-Mongolia:Centralaimak, Songino, $24 \mathrm{~km} \mathrm{SWvon} \mathrm{Ulan-}$ Baator, 1300m, 13.VII.1963, leg. Z. Kaszab (Nr. 113), 19; same locality, 7.VI.1966, leg. Z. Kaszab (Nr. 505), 19; Archangaj aimak, Changaj Gebirge, 8 km W von 
Somon Urdtamir, 1620m, 21.VII.1966, leg. Z. Kaszab (Nr. 724), 2 어영 Archangaj aimak, Chaalgsin chundi bei Somon Tövschruulech, $63 \mathrm{~km}$ O von Urdtamir, $1500 \mathrm{~m}, 22$. VII.1966, leg. Z. Kaszab (Nr. 727), 19; Central aimak, Toagoni ovoo, $10 \mathrm{~km}$ N von Ulan-Baator, 1700-1900m, 23-24.VII.1967, leg. Z. Kaszab (Nr. 926a), 1; Bajan-Ölgij aimak, im Tal des Flusses Chavcalyn gol, $25 \mathrm{~km}$ O von Somon Cagannuur, 1850m, 3.VII.1968, leg. Z. Kaszab (Nr. 1056), 1 워․

Remarks - First records for Mongolia. This species is widely distributed in the Palaearctic region (YU et al. 2012, RIEDEL 2017).

\section{Campoletis ensifera sp. $n$.}

(Fig. 1)

Material examined - Holotype: Mongolia, Bajan-Ölgij aimak, am Pass Schine davaa, $27 \mathrm{~km}$ S von Somon Cagannuur, 2690m, 30.VI.1968, leg. Z. Kaszab (Nr. 1045), 19; specimen pinned, Id. No. HNHM-HYM 153123. - Paratypes: Mongolia, Central aimak, Ulan-Baator, Nucht in Bogdo ul, 1880-2000m, 9.VI.1966, leg. Z. Kaszab (Nr. 508), 1 ; ; specimen pinned, Id. No. HNHM-HYM 153124; Uvs aimak, Pass Ulaan davaa, am östl. Hang, zw. See Örög nuur und Ulaagom, 1950m, 6.VII.1968, leg. Z. Kaszab (Nr. 1069), 10 ${ }^{\dagger}$; specimen pinned, Id. No. HNHM-HYM 153118.

Diagnosis - Among the Palaearctic species of the genus, Campoletis ensifera sp. n. is most similar to Campoletis fuscipes (Holmgren, 1856), Campoletis cubicator Aubert, 1974, and Campoletis tibetana (Kokujev, 1915), due to sharing the following characteristics: lack of distinct clypeal tooth, lower external angle of second discal cell about right-angled, tegula yellowish. The new species can be easily distinguished from Campoletis cubicator and from Campoletis tibetana by colouration: hind tibia entirely reddish brown in Campoletis ensifera sp. n., while externo-medially pale yellow in Campoletis cubicator or yellowish grey in Campoletis tibetana. Campoletis ensifera sp. n. can be distinguished from Campoletis fuscipes by length and shape of gena, length of ovipositor, and by colouration (gena long, in dorsal view $0.8-0.9 \times$ as long as eye width, weakly narrowed behind eye, ovipositor sheath as long as hind tibia, metasomal tergites predominantly blackish, second tergite with a narrow apical reddish band, extreme apical edges of other tergites very narrowly yellowish red in Campoletis ensifera sp. $\mathrm{n}$., while in Campoletis fuscipes gena short, in dorsal view 0.5-0.7x as long as eye width, distinctly narrowed behind eye, ovipositor sheath $0.70-0.75 \times$ as long as hind tibia, metasomal tergites $2-4$ entirely or predominantly reddish). The clypeal tooth is usually well developed in Campoletis crassicornis (Tschek, 1871), a species similar to the new species in colouration and in rightangled lower external corner of second discal cell, however, rarely the clypeal tooth is indistinct in this species; these specimens could be easily distinguished from the new species by the length of ovipositor: ovipositor sheath as long as hind 
tibia in Campoletis ensifera sp. n., while in Campoletis crassicornis $0.5-0.6 \times$ as long as hind tibia. ca $5 \mathrm{~mm}$.

Description - Female (Fig. 1). Body length ca 7-8 mm, fore wing length

Head: Antenna with 33 flagellomeres; basal flagellomeres relatively slender, first flagellomere ca $2.5 \times$ as long as wide apically; preapical flagellomeres wider than long. Head transverse, granulate, matt, with dense, whitish hairs. Ocularocellar distance $1.7 \times$ as long as ocellus diameter, posterior ocellar distance $2 \times$ as long as ocellus diameter. Inner eye orbits slightly indented, almost parallel. Gena (temple) long, in dorsal view about $0.8-0.9 \times$ as long as eye width, weakly narrowed behind eye. Occipital carina complete, ventral part distinctly bent outwards, reaching hypostomal carina distinctly before mandibular base; hypostomal carina slightly elevated. Malar space $0.7-0.8 \times$ as long as basal width of mandible. Face weakly convex in profile, maximum face width about as wide as frons below middle ocellus. Clypeus granulate with superficial punctures, weakly convex in profile, apical margin convex and weakly, lamelliformly produced medially, without distinct median tooth. Mandible relatively long, lower margin of mandible with narrow flange from teeth toward base, mandibular teeth of equal length.

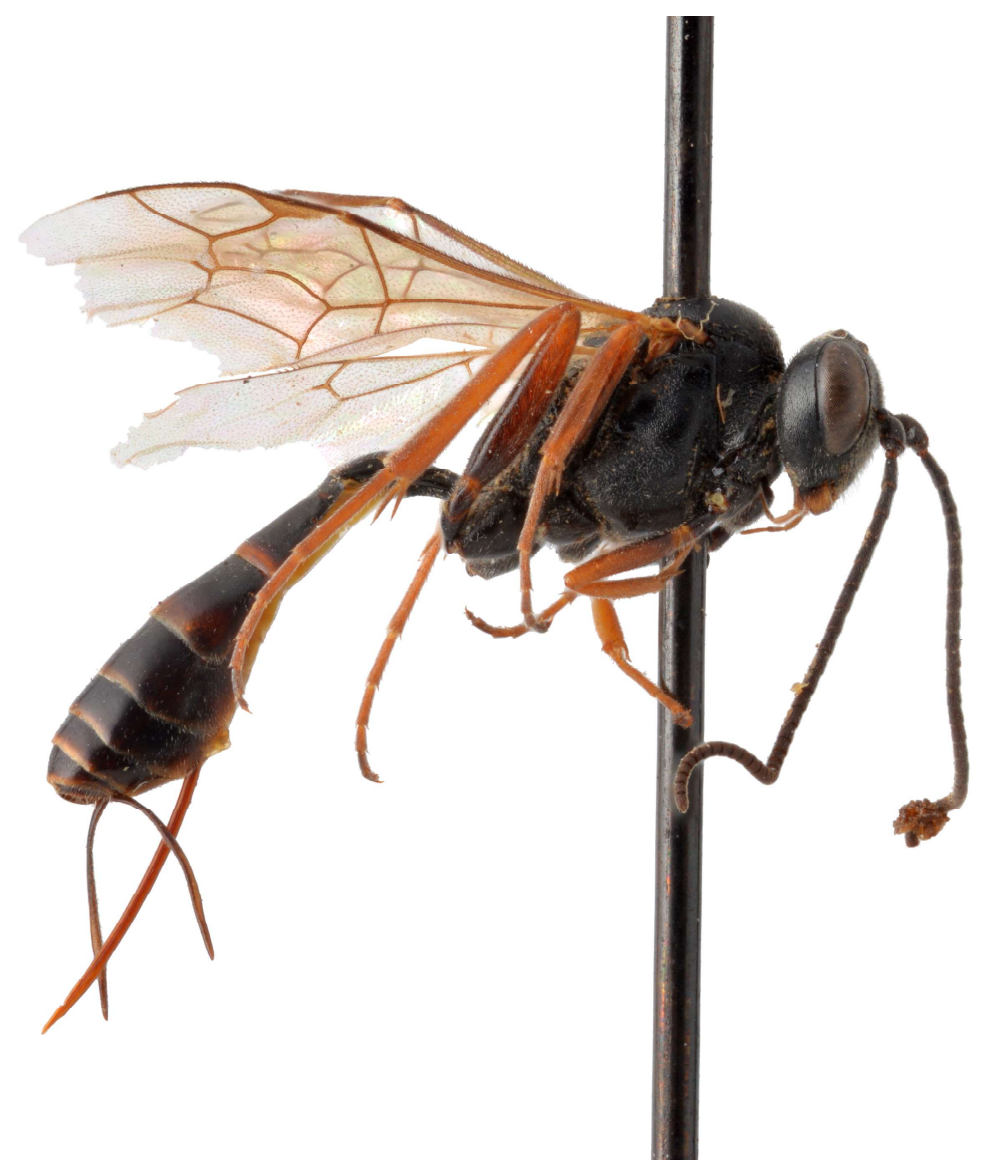

Fig. 1. Campoletis ensifera sp. n., holotype (photo by Tamás Németh) 
Mesosoma: Granulate with dense, short, whitish hairs, and with dense, superficial punctures on mesoscutum and mesopleuron. Pronotum with transverse wrinkles in ventral two-third. Mesoscutum convex in profile, about as long as wide, notaulus not developed. Scuto-scutellar groove deep and wide. Scutellum convex in profile, without lateral carina. Mesopleuron granulate, matt, speculum entirely or partly granulate; mesopleural suture deep with strong transverse costae. Sternaulus indistinct. Epicnemial carina complete, strong; pleural part of epicnemial carina slightly elevated, obliquely bent to anterior margin of mesopleuron reaching it below its middle height; ventral part of prepectal carina (behind fore coxae) slightly elevated, medially not excised; transversal part of epicnemial carina (i.e. part at the level of sternaulus running through the epicnemium to the ventral edge of pronotum) not developed. Posterior transverse carina of mesosternum complete, medially not excised. Metanotum short, about $0.5 \times$ as long as scutellum. Metapleuron granulate, without juxtacoxal carina; submetapleural carina complete, strong. Pleural carina of propodeum complete, strong; propodeal spiracle oval, separated from pleural carina by about its length, connected to pleural carina by a ridge. Propodeum granulate to rugose, propodeal carinae strong. Area basalis trapezoidal, wide, its basal width about $1.5-2.0 \times$ as long as its length. Area superomedia about as long as its maximum width, apically closed. Costula complete, connected to area superomedia at or little behind its middle. Area petiolaris long, distinctly, widely impressed with transverse wrinkles. Fore wing with short-stalked areolet, second recurrent vein $(2 m-c u)$ distinctly proximal to its middle, $3 r s-m$ weakly pigmented; distal abscissa of $R 1$ ca $1.5-1.6 \times$ as long as maximum width of pterostigma; distal abscissa of $R s$ about straight; nervulus $(c u-a)$ weakly postfurcal, inclivous; postnervulus (abscissa of $C u 1$ between $1 m-c u$ and $C u 1 \mathrm{a}+\mathrm{Cu} \mathrm{b}$ ) intercepted distinctly below middle by $C u 1$ a; lower external angle of second discal cell about right-angled. Hind wing with nervellus ( $c u-a+$ abscissa of $C u 1$ between $M$ and $c u-a$ ) intercepted at about lower 0.4 of its length, inclivous above interception, reclivous below interception; discoidella (distal abscissa of Cu1) complete, connected to nervellus, spectral. Coxae finely granulate. Fore tibia about $5 \times$ as long as its maximum width. Hind femur ca $5 \times$ as long as high. Inner spur of hind tibia ca $0.4 \times$ as long as first tarsomere of hind tarsus. Tarsal claws small, little longer than arolium, with $2-3$ basal pecten.

Metasoma: Finely granulate with short, relatively sparse, whitish hairs. First tergite about $2.3 \times$ as long as its apical width, glymma strong; dorsomedian carina of first tergite weak, on postpetiolus indistinct. Second tergite relatively stout, $1.1 \times$ as long as its apical width; thyridium short, oval, its distance from basal margin of tergite about 1.0-1.5 $\times$ as long as its length. Epipleurum of second and third tergites separated by a crease. Third tergite about as long as its apical width, following tergites all wider than long, medially not excised. Ovipositor sheath long, 1.4-1.5 $\times$ as long as first tergite, as long as hind tibia, ovipositor 
compressed, strong, almost straight to weakly upcurved, dorsal preapical notch deep.

Colour: Antenna blackish, apically brown. Head black except palpi yellowish brown and mandible yellow, basally blackish, mandibular teeth dark reddish brown. Mesosoma black except tegula yellowish. Metasoma: first tergite black, apically very narrowly reddish brown; second tergite black with a narrow (ca 0.12-0.13× tergite length) apical reddish band; third and following tergites blackish, extreme apical edges very narrowly yellowish red; ventral plica yellowish; ovipositor sheath dark brown. Wings hyaline, wing veins brown, pterostigma brown to yellowish brown. Fore leg: coxa black; trochanter black, apically narrowly yellowish; trochantellus predominantly dark brown, apically narrowly yellowish; femur reddish brown, basally dark brown, basal $0.3-0.5$ ventrally brown; tibia reddish brown; tarsus reddish brown, apical tarsomere brown. Middle leg: coxa black; trochanter black, apically narrowly yellowish; trochantellus predominantly dark brown, apically narrowly yellowish; femur reddish brown, basally dark brown, basal 0.4-0.6 ventrally dark brown; tibia reddish brown; tarsus reddish brown, apical tarsomere brown. Hind leg: coxa black; trochanter black, apically narrowly yellowish; trochantellus predominantly dark brown, apically narrowly yellowish; femur reddish brown, basally dark brown, basal $0.4-0.6$ ventrally dark brown; tibia reddish brown; tarsus reddish brown, apical tarsomere brown.

Male: Similar to female in all characters described above, except: antenna with 36 flagellomeres; preapical flagellomeres about quadrate to slightly longer than wide; area superomedia more elongate, about $1.3-1.4 \times$ as long as wide; costula connected to area superomedia before its middle; area petiolaris only moderately impressed; dorsomedian carina of first tergite somewhat stronger than in female; third tergite wider than long; clasper wide, apically rounded; apical reddish band of second tergite somewhat narrower than in female (ca $0.10 \times$ tergite length); fore and middle coxae apically yellowish; fore and middle trochanters predominantly yellowish; all trochantelli yellowish.

Distribution - Currently known from Mongolia.

Ecology - No host is known.

Etymology - The specific epithet ensifera is the feminine form of the Latin adjective ensifer, $-a$, -um meaning armed with a sword; it refers to the long and strong ovipositor of the new species.

Remarks - By using the identification key of the recent revision of Western Palaearctic Campoletis species (RIEDEL 2017), Campoletis ensifera sp. n. keys out at couplet 3 together with Campoletis fuscipes (Holmgren, 1856) and Campoletis cubicator Aubert, 1974, but without perfect match to either half of the couplet. The distinctive characteristics from these species are given in the Diagnosis section. 
Campoletis fuscipes (Holmgren, 1856)

Material examined - Mongolia: Central aimak, Songino, $24 \mathrm{~km} \mathrm{SW}$ von Ulan-Baator, 1300m, 7.VI.1966, leg. Z. Kaszab (Nr. 505), 19; Central aimak, Toagoni ovoo, 5-10 km N von Ulan-Baator, 1500-1600m, 4.VI.1967, leg. Z. Kaszab (Nr. 766), 19; Central aimak, $12 \mathrm{~km} \mathrm{~S}$ von Somon Bajan-baraat, 1380m, 13.VII.1967, leg. Z. Kaszab (Nr. 918), 1 ㅇ.

Remarks - First records for Mongolia. This species is known from several countries of the Western Palaearctic region, and from Kazakhstan (YU et al. 2012, RIEDEL 2017, VAS 2019a); hence, the present records represent the easternmost localities of the distribution of this species.

Campoletis latrator (Gravenhorst, 1829)

Material examined - Mongolia: Central aimak, Ulan-Baator, Nucht in Bogdo ul, 1950m, 4.VI.1966, leg. Z. Kaszab (Nr. 497), 1 우.

Remarks - First record for Mongolia. This species is known from several countries of the Western Palaearctic region, and from Iran (YU et al. 2012, MASNADi-YAzDinejad et al. 2010, Riedel 2017); hence, the present record represents the easternmost localities of the distribution of this species.

\section{Campoletis pectalis Riedel, 2017}

Material examined - Mongolia: Ulan-Bator, 1309m, 13.V.-4.VI.1964, leg. Mongolisch Deutsche Biolog. Exped. 1964, 1\%; Central aimak, Ulan-Baator, Nucht in Bogdo ul, 1650m, 4.VI.1966, leg. Z. Kaszab (Nr. 493), 1\%; Central aimak, Ulan-Baator, Zaisan im Bogdo ul, 1600m, 6.VI.1966, leg. Z. Kaszab (Nr. 499), 1 ; Central aimak, SO von Somon Bajanzogt, 1600m, 11.VI.1966, leg. Z. Kaszab (Nr. 519), 1 ${ }^{\lambda}$; Central aimak, Toagoni ovoo, $6-10 \mathrm{~km} \mathrm{~N}$ von Ulan-Baator, $1700 \mathrm{~m}$, 7-8.VI.1968, leg. Z. Kaszab (Nr. 938), 2 ; Bajan-Ölgij aimak, NO Ecke des Sees Tolbo nuur, 2100m, 26.VII.1968, leg. Z. Kaszab (Nr. 1151), $2 \AA$.

Remarks - First records for Mongolia. This species is known from a few countries of the Western Palaearctic region (RIEDEL 2017); hence, the present records represent the first report of this species from the Eastern Palaearctic region.

\section{Campoletis procera (Brischke, 1880)}

Material examined - Mongolia: Central aimak, Ulan-Baator, Nucht in Bogdo ul, 1950m, 4.VI.1966, leg. Z. Kaszab (Nr. 497), 19; Central aimak, UlanBaator, Zaisan im Bogdo ul, 1600m, 6.VI.1966, leg. Z. Kaszab (Nr. 499), 1 ㅇ․ 
Remarks - First records for Mongolia. This species is known from several countries of the Western Palaearctic region (YU et al. 2012, RIEDEL 2017); hence, the present record represents the first report of this species from the Eastern Palaearctic region.

Nomenclatural note - This species, originally described as Limneria procera Brischke, 1880, was transferred to the genus Campoletis Förster, 1869 by RIEDEL (2017) as Campoletis procerus (Brischke, 1880) comb. n. However, as the grammatical gender of the genus Campoletis is feminine (HOPPER 1959, YU et al. 2012), in this combination the grammatically correct specific epithet is procera (the feminine form of the Latin adjective procerus, $-a,-u m$ ).

\section{Campoletis varians (Thomson, 1887)}

Material examined - Mongolia: Central aimak, Ulan-Baator, Nucht in Bogdo ul, 1800-2000m, 27.VII.1966, leg. Z. Kaszab (Nr. 746), 1; Central aimak, $11 \mathrm{~km}$ OSO von Somon Bajanzogt, 1600-1700m, 26.VII.1968, leg. Z. Kaszab (Nr. 1150), 1 .

Remarks - First records for Mongolia. This species is known from several countries of the Western Palaearctic region, and from Siberia (Russia) (Yu et al. 2012, RiEDEL 2017, VAS 2019a).

\section{Campoletis viennensis (Gravenhorst, 1829)}

Material examined - Mongolia: Central aimak, Borulcin tala, $100 \mathrm{~km}$ So von Ulanbaator, 1400m, 5.VII.1963, leg. Z. Kaszab (Nr. 90), 19; Central aimak, Ganz modi dava, $66 \mathrm{~km}$ OSO von Ulanbaator, 1700m, 5.VII.1963, leg. Z. Kaszab (Nr. 94), 19; Central aimak, Zuum-Chara, 1390m, 8.VII.1963, leg. Z. Kaszab (Nr. 98), 2+; Uburchangaj aimak, Changaj Gebirge, $8 \mathrm{~km} \mathrm{~S}$ von Charchorin, $1600 \mathrm{~m}, 30 . V I .1964$, leg. Z. Kaszab (Nr. 231), 1 ; Bulgan aimak, $5 \mathrm{~km} \mathrm{O}$ von Somon Abzaga, 1400m, 2.VII.1964, leg. Z. Kaszab (Nr. 251), 1क; Gobi-Altaj aimak, Zavchan-Niederung ca. $20 \mathrm{~km} \mathrm{~N}$ von Zargalan, 1450m, 22-24.VI.1964, leg. Mongolisch Deutsche Biolog. Exped. 1964, 1; Uvs aimak, Burgastyn-gol im Turgen-ul, 1850m, 31.VII.-3.VIII.1964, leg. Mongolisch Deutsche Biolog. Exped. 1964, 19; Chentej aimak, $150 \mathrm{~km}$ ONO von Öndörchaan, $10 \mathrm{~km} \mathrm{~S}$ vom Kerulen, 1000m, 30.VII.1965, leg. Z. Kaszab (Nr. 331), 19; Chentej aimak, Somon Tumunzogt, $160 \mathrm{~km}$ ONO von Öndörchaan, 1000m, 31.VII.1965, leg. Z. Kaszab (Nr. 338), 1 9 ; Gobi Altaj aimak, Chasat chajrohan ul Gebirge, cca $20 \mathrm{~km} \mathrm{~S}$ von Somon Zargalan, 2400m, 15-16.VII.1966, leg. Z. Kaszab (Nr. 693, 697), 1 1 $1{ }^{\lambda}$; Archangaj aimak, Changaj Gebirge, 8 km W von Somon Urdtamir, 1620m, 21.VII.1966, leg. Z. Kaszab (Nr. 724), 49; Archangaj aimak, Chaalgsin chundi bei Somon Tövschruulech, $63 \mathrm{~km}$ O von Urdtamir, 1500m, 
22.VII.1966, leg. Z. Kaszab (Nr. 727), 19; Mittelgobi aimak, $20 \mathrm{~km} \mathrm{~S} \mathrm{von} \mathrm{Somon}$ Delgerzogt, 1480m, 13-14.VII.1967, leg. Z. Kaszab (Nr. 915), 2 ; Central aimak, $12 \mathrm{~km} \mathrm{~S}$ von Somon Bajan-baraat, 1380m, 13.VII.1967, leg. Z. Kaszab (Nr. 918), 1 ; Central aimak, Toagoni ovoo, $10 \mathrm{~km} \mathrm{~N}$ von Ulan-Baator, 1700-1900m, 23-24.VII.1967, leg. Z. Kaszab (Nr. 926a), 1 우웅 Central aimak, Ulan-Baator, Nucht im Bogdo ul, 1500-1600m, 21.VII.1967, leg. Z. Kaszab (Nr. 931), 19; Uva aimak, zw. See Örög nuur und Ulaangom, 2-7 km OSO vom Pass Ulaan davaa, 1690-1950m, 20.VI.1968, leg. Z. Kaszab (Nr. 1032), 3워형 Bajan-Ölgij aimak, im Tal des Flusses Chavcalyn gol, $25 \mathrm{~km}$ O von Somon Cagannuur, $1850 \mathrm{~m}$, 3.VII.1968, leg. Z. Kaszab (Nr. 1056), $22^{2}{ }^{\wedge}$; Uvs aimak, Pass Ulaan davaa, am östl. Hang, zw. See Örög nuur und Ulaagom, 1950m, 6.VII.1968, leg. Z. Kaszab (Nr. 1069), 4ำ ${ }^{\wedge}$; Uva aimak, $2 \mathrm{~km}$ O von Pass Ulaan davaa, zw. See Örög nuur und Ulaangom, 1950m, 6.VII.1968, leg. Z. Kaszab (Nr. 1071), 5\%; Zavchan aimak, Choit chunch, $26 \mathrm{~km}$ ONO von See Temen nuur, 2150m, 13.VII.1968, leg. Z. Kaszab (Nr. 1104), 1 ; Chövsgöl aimak, $10 \mathrm{~km}$ NO vom Fluss Delger mörön, $16 \mathrm{~km} \mathrm{~N}$ von Somon Burenchaan, 1700m, 17.VII.1968, leg. Z. Kaszab (Nr. 1118), 1 '; Central aimak, $11 \mathrm{~km}$ OSO von Somon Bajanzogt, 1600-1700m, 26.VII.1968, leg. Z. Kaszab (Nr. 1150), 1 ㅇ․

Remarks - First records for Mongolia. This species is widely distributed in the Palaearctic region (YU et al. 2012, RIEDEL 2017, VAs 2019a).

\section{Casinaria camura Vas, 2019}

Material examined - Mongolia: Central aimak, Ulan-Baator, Nucht in Bogdo ul, 1880-2000m, 9.VI.1966, leg. Z. Kaszab (Nr. 508), 1 万.

Remarks - This species was recently described from Mongolia (VAs 2009d).

First description of male sex - This species was described and is known by female sex (VAs 2009d); the male is similar to female in all characters described by VAs (2009d), except: body length ca $7.5 \mathrm{~mm}$; first flagellomere $2 \times$ as long as wide apically; rugosity and punctures of mesosoma somewhat stronger than in female; areolet short-stalked; nervellus weakly inclivous; hind femur ca $4.3 \times$ as long as high; second tergite $1.5 \times$ as long as its apical width; hind femur predominantly reddish; hind tibia predominantly reddish, basally yellowish, subbasally weakly, apically strongly darkened; basal 0.4 of first tarsomere of hind tarsus yellowish. Description of the male sex is based on the above reported male specimen, Id. No. HNHM-HYM 111488.

\section{Leptocampoplex cremastoides (Holmgren, 1860)}

Materialexamined-Kosovo[onlabel:Yugoslavia,Kosovo]: Gjakova[onlabel: Djakovica], Brenik, 500m, 19.V.1971, leg. J. Papp \& S. Horvatovich (Nr. 15), 1 ․ . - 
Republic of North Macedonia [on label: Yugoslavia, Macedonia]: Lake Dojran, 150-500m, 9-10.V.1971, leg. J. Papp \& S. Horvatovich (Nr. 7), 1 ㅇ.

Remarks - First records for Republic of North Macedonia and for Kosovo. This species is widely distributed in the Holarctic region (Yu et al. 2012, Di GiovanNi \& RESHCHIKOV 2016).

\section{Leptoperilissus ibericus Horstmann, 1987}

Material examined - Algeria: Oran, El-Ancor Foret de M’Sila, 25.IV.1986, leg. I. Rozner, 1 1 1 万.

Remarks - First record for Algeria. This species has been known from Spain so far (HoRstMANN 1987, 1993, YU et al. 2012).

First description of male sex - This species was described and is known by female sex (HORSTMANN 1987); the original description is fairly detailed, and subsequently a few more morphological details were given in the revision of the genus (HORSTMANN 1993). Hence, a complete re-description of the species is not necessary. Sexual dimorphism is rather slight, male is similar to female in all characters described by HoRstMANN (1987, 1993), except: body length ca $4 \mathrm{~mm}$; antenna with 26 flagellomeres; punctures on mesopleuron very weak and superficial; nervulus interstitial; hind femur more slender, $4 \times$ as long as high; area basalis triangular; area superomedia narrower than in females; first and second tergites little slenderer than in females; clasper short, broad; hind femur blackish. Description of the male sex is based on the above reported male specimen, Id. No. HNHM-HYM 154140. By using the identification key in HORSTMANN's (1993) revision the male correctly keys out together with the female at the first half of couplet 4 .

\section{Leptoperilissus maroccanus Horstmann, 1993}

Material examined - Spain: Catalonia, Mt. de St. Mame, Figuerola de Meiá, 700m, 23-24.V.2001, leg. A. Orosz, 1 ㅇ․

Remarks - First record for Spain. This species has been known from Morocco so far (HORSTMANN 1993, YU et al. 2012).

\section{Meloboris collector (Thunberg, 1822)}

Material examined - Armenia [on label: USSR Armenia]: Djrvezh, $1300 \mathrm{~m}$, 30.V.1980, leg.J. Papp, 19. - Jordan: Amman [on label: N.Amm.], 1000m, 5.V.1956, leg. J. Klapperich, 2o. - Kosovo [on label: Yugoslavia, Kosovo]: Gjakova [on label: Djakovica], Brenik, 500m, 19.V.1971, leg. J. Papp \& S. Horvatovich 
(Nr. 15), 19; Mts. Sar, Brezovica, 900-1200m, 20-23.V.1971, leg. J. Papp \& S. Horvatovich (Nr. 16), 1ㅇ. - Serbia [on label: Yugoslavia]: Bečej [on label: Becse], 20.VII.1970, leg. unknown, 1 万.

Remarks - First records for Armenia, Jordan, Kosovo and Serbia. This species is widely distributed in the Palaearctic region (YU et al. 2012).

\section{Meloboris moldavica (Constantineanu et Mustata, 1972)}

Material examined - Hungary: Bács-Kiskun county, Kunfehértó, 18.IV.1979, leg. J. Papp, 2 . . - Mongolia: Central aimak, $11 \mathrm{~km} \mathrm{~S} \mathrm{vom} \mathrm{Pass} \mathrm{Zosijn}$ davah, $90 \mathrm{~km}$ S von Ulan-Baator, 1650m, 7.VI.1967, leg. Z. Kaszab (Nr.771), 1ㅇ. Portugal: Tomar, 12.V.1991, leg. A. Podlussány, 1․ - Turkmenistan: $50 \mathrm{~km} \mathrm{~N}$ of Ashkhabad, 58 $33^{\circ} \mathrm{E}, 38^{\circ} 22^{\prime} \mathrm{N}, 100 \mathrm{~m}, 6 . \mathrm{IV} .1993$, leg. M. Hreblay, Gy. László \& A. Podlussány (No. L84), 1 ㅇ․

Remarks - First records for Hungary, Mongolia, Portugal and Turkmenistan. This species has been described and known from Romania so far (Constantineanu \& Mustata 1972, Yu et al. 2012); these records also represent the first reports of this species from the Eastern Palaearctic region.

\section{Meloboris sagittaria sp. $n$.}

(Fig. 2)

Material examined - Holotype: Mongolia, Central aimak, Ulan-Baator, 1300-1400m a. linken Ufer des Tola, 11.VI.1964, leg. Z. Kaszab (Nr. 117), 1 ; ; specimen pinned, Id. No. HNHM-HYM 111490. - Paratype: Mongolia, Central aimak, Ulan-Baator, Nucht im Bogdo ul, 1500-1600m, 21.VII.1967, leg. Z. Kaszab (Nr. 931), 19; specimen pinned, Id. No. HNHM-HYM 111491.

Diagnosis - Meloboris sagittaria sp. n. can be distinguished from all other Palaearctic species of the genus by the following combination of characters: posterior transverse carina of mesosternum interrupted in front of middle coxae; first tergite long, slender, glymma small but strong, deep; area superomedia conspicuously elongated and narrow, 2.2-2.5x as long as its maximum width; areolet broadly sessile; nervulus only weakly postfurcal; gena short, strongly narrowed behind eye; fore and middle coxae yellow, basally brownish; hind trochanter predominantly brownish; hind tibia brownish, externo-medially somewhat lighter, faint yellowish brown, basal lighter spot missing or rather indistinct. The new species is most similar in general habitus to the Palaearctic species Meloboris collector (Thunberg, 1822) and to the Eastern Palaearctic (Japanese) species Meloboris xylostellae Kusigemati, 1993; both species differ from the new species in the length and shape of area superomedia, in the colouration of legs, and, additionally, Meloboris collector differs from the new species by having 
petiolate areolet and weak glymma. Meloboris moldavica (Constantineanu et Mustata, 1972) sometimes has nearly as elongate area superomedia as the new species, but this species can be readily distinguished from Meloboris sagittaria sp.n. by its very strongly postfurcal nervulus, and by colouration of hind leg.

Description - Female (Fig. 2). Body length ca 5-6 mm, fore wing length ca $4.5 \mathrm{~mm}$.

Head: Antenna with 26-30 flagellomeres; basal flagellomeres long and slender, first flagellomere ca $4.5 \times$ as long as wide apically; preapical flagellomeres longer than wide. Head transverse, granulate, matt, with dense, whitish hairs. Ocular-ocellar distance $1.5-1.7 \times$ as long as ocellus diameter, posterior ocellar distance $1.5 \times$ as long as ocellus diameter. Inner eye orbits slightly indented and weakly convergent ventrally. Gena (temple) short, in dorsal view about $0.5-0.6 \times$ as long as eye width, strongly narrowed behind eye. Occipital carina complete, reaching hypostomal carina distinctly before mandibular base; hypostomal carina not elevated. Malar space $0.7-0.8 \times$ as long as basal width of mandible. Face flat in profile, maximum face width about $0.85 \times$ as wide as frons below middle ocellus. Clypeus almost flat in profile, apical margin weakly, evenly convex. Mandible relatively short, lower margin of mandible with relatively wide flange from teeth toward base, lower mandibular tooth slightly shorter and smaller than upper mandibular tooth.

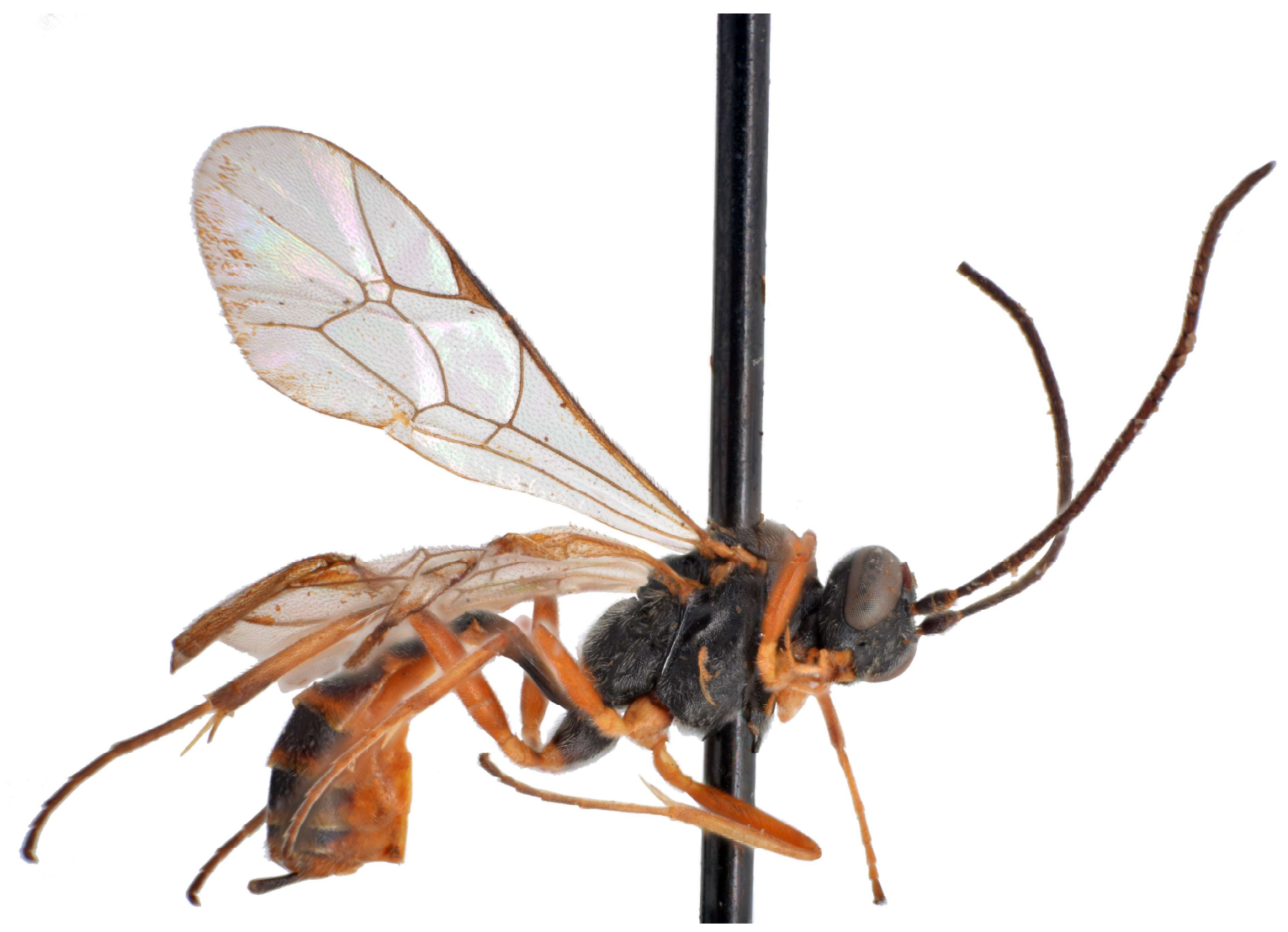

Fig. 2. Meloboris sagittaria sp. n., holotype (photo by Tamás Németh) 
Mesosoma: Granulate with dense, moderately long, whitish hairs, and with at most some inconspicuous, superficial punctures on mesoscutum. Pronotum with transverse wrinkles in ventral two-third; epomia distinct, strong. Mesoscutum convex in profile, slightly longer than wide, notaulus not developed. Scuto-scutellar groove deep and wide. Scutellum convex in profile, without lateral carina. Mesopleuron granulate, matt, speculum smooth, shiny; mesopleural suture with few distinct, short, transverse costae. Sternaulus indistinct. Epicnemial carina complete, strong; pleural part of epicnemial carina not elevated, obliquely bent to anterior margin of mesopleuron reaching it at about its middle height; ventral part of prepectal carina (behind fore coxae) not elevated, medially slightly excised; transversal part of epicnemial carina (i.e. part at the level of sternaulus running through the epicnemium to the ventral edge of pronotum) not developed. Posterior transverse carina of mesosternum incomplete: laterally present, then widely interrupted, missing before each middle coxa, then a short, slightly excised medial section present. Metanotum short, about $0.5 \times$ as long as scutellum. Metapleuron granulate; juxtacoxal carina indistinct; submetapleural carina complete, strong. Pleural carina of propodeum complete, strong; propodeal spiracle oval, separated from pleural carina by less than its length, connected to pleural carina by a ridge. Propodeum relatively long, granulate to rugose; longitudinal carinae of propodeum complete but relatively weak, transverse carinae partly obsolescent. Area basalis trapezoidal, relatively long and wide, its basal width about as long as its length, area basalis little wider than area superomedia. Area superomedia conspicuously long and narrow, about $2.2-2.5 \times$ as long as its maximum width, its lateral sides strongly convergent apically behind costula, apically very narrow, opened. Costula proximally strong, distally weak to obsolescent, connected to area superomedia before its middle. Area petiolaris weakly impressed, covered with transverse wrinkles, basally narrow, strongly widened apically. Fore wing with relatively large, broadly sessile areolet, anterior distance between $2 r s-m$ and $3 r s-m$ almost half as long as $2 r s-m$; $3 r s-m$ pigmented; second recurrent vein $(2 m-c u)$ distal to middle of areolet; distal abscissa of $R 1$ ca $1.4 \times$ as long as maximum width of pterostigma; distal abscissa of $R s$ almost straight, its distal third slightly curved toward front margin; nervulus $(c u-a)$ weakly postfurcal, inclivous; postnervulus (abscissa of $\mathrm{Cu} 1$ between $1 \mathrm{~m}$-cu and $C u 1 \mathrm{a}+C u 1 \mathrm{~b})$ intercepted little below middle by $C u 1 \mathrm{a}$; lower external angle of second discal cell acute. Hind wing with nervellus (cu-a + abscissa of $\mathrm{Cu} 1$ between $M$ and $c u-a$ ) intercepted at about lower 0.3 of its length, vertical to weakly reclivous; discoidella (distal abscissa of $\mathrm{Cu}$ ) complete, connected to nervellus, spectral. Coxae finely granulate. Hind femur ca $5 x$ as long as high. Inner spur of hind tibia ca $0.5-0.6 \times$ as long as first tarsomere of hind tarsus. Tarsal claws small, about as long as or shorter than arolium, with few basal pecten.

Metasoma: Finely granulate with short, moderately dense, whitish hairs. First tergite slender, almost $3 \times$ as long as its apical width, glymma small but strong, deep; dorsomedian carina of first tergite on petiolus distinct, on postpetiolus 
inconspicuous. Second tergite relatively stout, about $1.2-1.3 \times$ as long as its apical width; thyridium large, circular, its distance from basal margin of tergite about $1.5-2.0 \times$ as long as its length. Epipleurum of second and third tergites separated by a crease. Third tergite about as long as its apical width, following tergites all wider than long, medially not excised. Ovipositor sheath straight, short, ca $0.65 \times$ as long as first tergite, ca $0.3 \times$ as long as hind tibia.

Colour: Antenna dark brown, apically brown; scapus apically narrowly yellowish, pedicellus apically narrowly to on ventral side predominantly yellowish. Head black except palpi and mandible yellowish, mandibular teeth dark reddish brown. Mesosoma black except tegula yellow. Metasoma blackish, all tergites except first with reddish apical bands and reddish epipleura; ventral plica reddish yellow; ovipositor sheath dark brown. Wings hyaline, wing veins brown, pterostigma brown to yellowish brown. Fore leg: coxa predominantly yellow, basally brownish; trochanter and trochantellus yellow; femur, tibia and tarsus yellowish to reddish, apical tarsomere brownish. Middle leg: coxa predominantly yellow, basally brownish; trochanter and trochantellus yellow; femur, tibia and tarsus yellowish red to reddish, apical tarsomeres brownish. Hind leg: coxa black, apically narrowly yellowish; trochanter brownish, apically narrowly yellowish; trochantellus yellowish; femur reddish to brownish, at least basally and apically darkened, or almost entirely dark brownish on outer side; tibia brownish, externo-medially somewhat lighter, faint yellowish brown, basal lighter spot missing or rather indistinct; tarsus brown.

Male: Unknown.

Distribution - Currently known from Mongolia.

Ecology - No host is known.

Etymology - The specific epithet sagittaria is the feminine form of the Latin adjective sagittarius, $-a$, - um meaning armed with arrows and bow; it refers to the conspicuously long and narrow area superomedia of the new species, which is shaped like a backward pointing arrowhead.

Phobocampe bicingulata (Gravenhorst, 1829)

Material examined - Armenia [on label: USSR Armenia]: Cakhadzor, $1850 \mathrm{~m}, 14 . V$ III.1976, leg. T. Vásárhelyi, 1 ㅇ․

Remarks - First record for Armenia. This species is widely distributed in the Holarctic region (YU et al. 2012). 


\section{Phobocampe tempestiva (Holmgren, 1860)}

Material examined - Hungary: Pest county, Nagybörzsöny, Farkas valley [on label: Farkas-völgy], 10.VI.2015, leg. O. Merkl, 2 ${ }^{+}$. - Switzerland [on label: Helvetia]: Lugano, Mt. Generoso, 11.VII.1980, leg. J. Papp, 1 ㅇ.

Remarks - First records for Hungary and for Switzerland. This species is known from several countries of the Western Palaearctic region (YU et al. 2012).

Porizon transfuga (Gravenhorst, 1829)

Material examined - Bulgaria: Sofia, Vitosha Mts, 1000m, 15.VIII.1982, leg. Draskovits \& Váli (Nr. 33), 1ㅇ. - Hungary: Győr-Moson-Sopron county, Fenyőfö, Mt. Kőris [on label: Kőris-hegy], 18.VIII.1970, leg. J. Papp, 1 ㅇ․

Remarks - First records for Bulgaria and for Hungary. This species is widely distributed in the Western Palaearctic region (Yu et al. 2012). Yu et al. (2012) list this species as known from Hungary citing ZILAHI-KISs (1924, 1926, 1933); however, all of these records refer either to localities in present-day Romania (ZILAHI-KISs 1924, 1926) or to specimens misidentified by Zilahi-Kiss (ZILAHIKIss 1933).

\section{Pyracmon fumipennis (Zetterstedt, 1838)}

Material examined- Slovakia: Košice Region, Sobrance [on label: Szobráncz], 1875, leg. S. Mocsáry, 1 $\hat{\text {. }}$ - Montenegro: Durmitor, Tara Valley [on label: Tara-völgy], 4.VII.1958, leg. Mihályi, 10 . - Republic of North Macedonia [on label: Yugoslavia, Macedonia]: Jakupica Mts., 1400m, 28.VII.1967, leg. S. Horvatovich, $1 \overbrace{}^{\hat{\gamma}}$.

Remarks - First records for Slovakia, for Montenegro, and for Republic of North Macedonia. This species is widely distributed in the Western Palaearctic region (Yu et al. 2012).

\section{Rhimphoctona longicauda Horstmann, 1980}

Material examined - Romania: Mureş county, Saschiz [on label: Siebenbuergen, Kaisd-Saschiz], date unknown, leg. Sielbernagel, 1 우.

Remarks - First record for Romania. This species is widely distributed in the Western Palaearctic regions (Yu et al. 2012). 
Rhimphoctona megacephalus (Gravenhorst, 1829)

Material examined - Romania: Mureş county, Saschiz [on label: Szászkézd], date unknown, leg. Sielbernagel, 19.; Mureş county, Saschiz [on label: Siebenbuergen, Kaisd-Saschiz], date unknown, leg. Sielbernagel, $1{ }^{\top}$; Cluj county, Ocna Dejului [on label: Désakna], date unknown, leg. E. Zilahi-Kiss, 1 ; ; Sălaj county, Zalău [on label: Zilah], 1925, leg. Tréger, 1 iq.

Remarks - First records for Romania. This species is widely distributed in the Palaearctic region (Yu et al. 2012).

Rhimphoctona rufocoxalis (Clément, 1924)

Material examined - Slovakia: Dolný Smokovec [on label: A.T.Füred $=$ Alsótátrafüred], date unknown, leg. Gy. Szépligeti, 3 ㅇ.

Remarks - First record for Slovakia. This species is widely distributed in the Palaearctic region (YU et al. 2012).

\section{Rhimphoctona teredo (Hartig, 1847)}

Material examined - Slovakia: Mlynčeky [on label: Tátraháza], date unknown, leg. Gy. Szépligeti, 1+; Dolný Smokovec [on label: A.T.Füred $=$ Alsótátrafüred], date unknown, leg. Gy. Szépligeti, 1 ㅇ․

Remarks - First records for Slovakia. This species is widely distributed in the Western Palaearctic region ( $\mathrm{Yu}$ et al. 2012).

\section{Venturia atrata sp. n.}

(Fig. 3)

Material examined - Holotype: Mongolia, Central aimak, $11 \mathrm{~km} \mathrm{~S} \mathrm{vom} \mathrm{Pass}$ Zosijn davaa, $90 \mathrm{~km}$ S von Ulan-Baator, 1650m, 7.VI.1967, leg.Z. Kaszab (Nr. 767), 19; specimen pinned, Id. No. HNHM-HYM 153150.

Diagnosis - Among the Palaearctic species of the genus, the new species is most similar to the Eastern Palaearctic species Venturia mongolica (Kokujev, 1915), and to the Western Palaearctic species Venturia atricolor (Györfi, 1946) due to sharing the following characteristics: head and mesosoma distinctly, densely punctate; propodeum short, its apex not reaching middle length of hind coxa; area superomedia short, at most $1.5 \times$ as long as wide; body (except legs) predominantly black, mandible and tegula yellow, hind tibia externo-medially not yellowish. The new species can be easily distinguished from both by the following combination of characters: scapus, fore and middle trochanters blackish, middle 
femur predominantly blackish, hind femur almost entirely black, tarsal claws with conspicuously strong, teeth-like pecten almost all along their lengths, ovipositor sheath as long as hind tibia (while scapus ventrally reddish, fore and middle trochanters entirely to predominantly yellowish or reddish, middle femur reddish, hind femur entirely to predominantly reddish to reddish brown, tarsal claws only with weak, basal pecten, ovipositor sheath $1.2-1.3 \times$ as long as hind tibia in the above mentioned species). Additionally, Venturia atrata sp. n. differs from Venturia mongolica by the following: surface of head and mesosoma less smooth and shiny, more granulate, mesosoma more robust, apical tergites medially less deeply excised than in Venturia mongolica, and nervellus intercepted at lower 0.3 of its length (in Venturia mongolica intercepted at lower 0.5 of its length). Venturia atrata sp. n., besides the above mentioned, differs from Venturia atricolor by the following: surface of head and mesosoma less coarsely granulate, lower external angle of second discal cell about right-angled, areolet short-stalked (in Venturia atricolor lower external angle of second discal cell acute, areolet not petiolate).

Description - Female (Fig. 3). Body length ca $6 \mathrm{~mm}$, fore wing length ca $4.5 \mathrm{~mm}$.

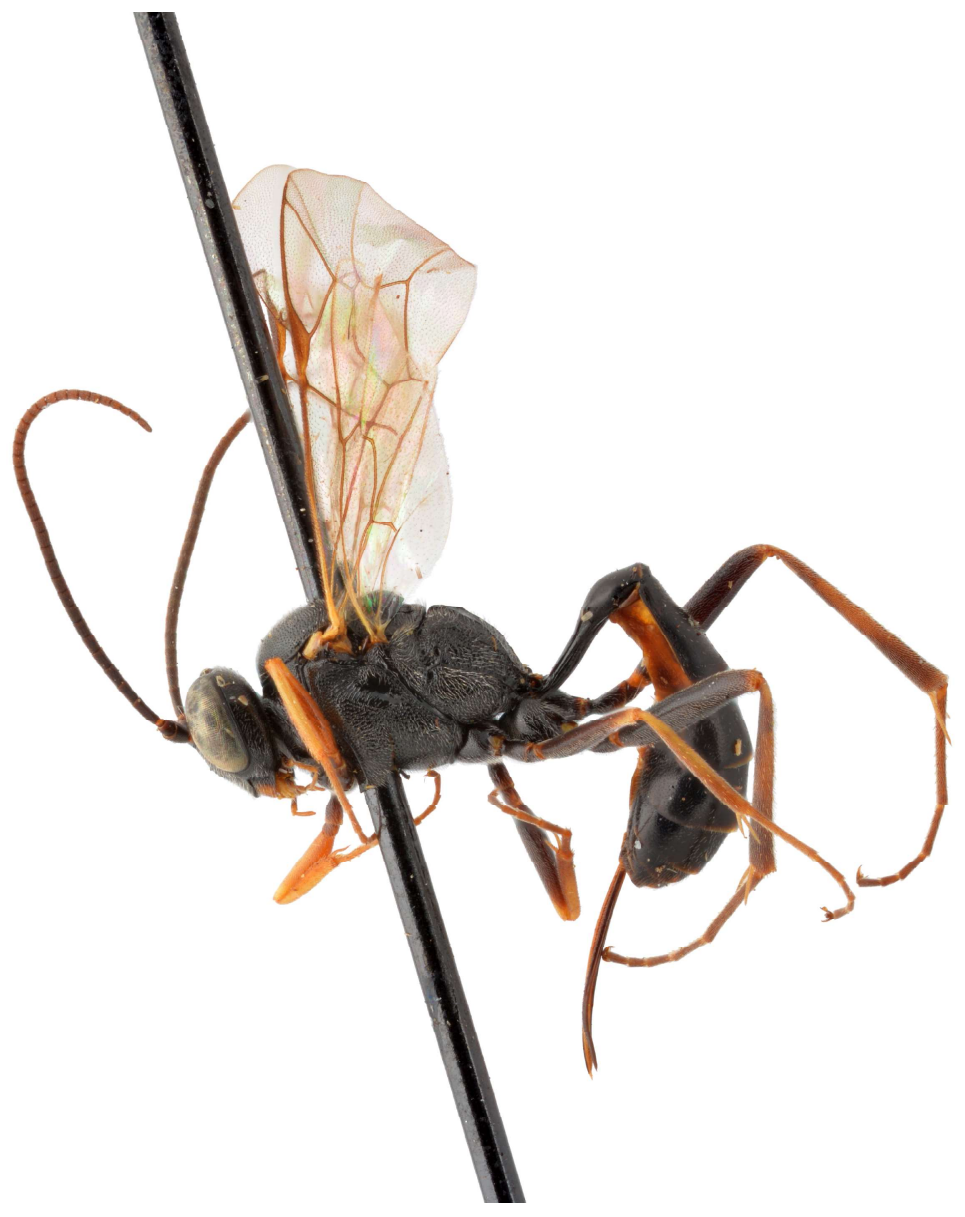

Fig. 3. Venturia atrata sp. n., holotype (photo by Tamás Németh) 
Head: Antenna with 34 flagellomeres; first flagellomere ca $3.3 \times$ as long as wide apically; preapical flagellomeres square to slightly longer than wide. Head transverse, rather densely and distinctly punctate on finely granulate to coarsely rugose surface, and with dense, whitish hairs. Ocular-ocellar distance about as long as ocellus diameter, posterior ocellar distance about twice as long as ocellus diameter. Inner eye orbits weakly indented, ventrally convergent. Gena (temple) finely granulate with dense punctures, short, in dorsal view about $0.55 \times$ as long as eye width, moderately narrowed behind eye. Occipital carina complete, reaching hypostomal carina distinctly before mandibular base; hypostomal carina not elevated. Malar space granulate, very short, $0.3-0.4 \times$ as long as basal width of mandible. Face coarsely rugose-punctate, matt, flat in profile, maximum face width about $0.85 \times$ as wide as frons below middle ocellus. Clypeus laterally granulate, medially partly smooth with relatively large punctures, almost flat in profile, rather wide, apical margin weakly convex. Mandible relatively long, lower margin of mandible with narrow flange from teeth toward base, mandibular teeth of equal length.

Mesosoma: Relatively stocky and robust, about $0.65 \times$ as high as long in profile, rather densely and distinctly punctate on very finely granulate to rugose surface, moderately shiny to matt, and with dense, short, whitish hairs. Pronotum with strong, rather shiny transverse wrinkles in ventral two-third; epomia distinct, strong. Mesoscutum strongly, densely punctate on finely granulate (at some parts almost smooth) surface, convex in profile, slightly longer than wide, notaulus not developed. Scuto-scutellar groove deep and wide. Scutellum convex in profile, without lateral carina. Mesopleuron strongly, densely punctate on finely granulate (at some parts almost smooth) surface, speculum smooth, shiny, with strong, short diagonal wrinkles anterior to speculum; mesopleural suture not impressed. Sternaulus indistinct. Epicnemial carina complete, strong; pleural part of epicnemial carina not elevated, obliquely bent to anterior margin of mesopleuron reaching it below its middle height; ventral part of prepectal carina (behind fore coxae) not elevated, medially not excised; transversal part of epicnemial carina (i.e. part at the level of sternaulus running through the epicnemium to the ventral edge of pronotum) not developed. Posterior transverse carina of mesosternum complete. Metanotum about $0.5 \times$ as long as scutellum. Metapleuron rather densely and distinctly punctate on finely to distinctly granulate surface; juxtacoxal carina absent; submetapleural carina complete, strong. Pleural carina of propodeum complete; propodeal spiracle oval, separated from pleural carina by less than its length, connected to pleural carina by a ridge. Propodeum short, its apex distinctly not reaching middle length of hind coxa, granulate to rugose with dense, distinct punctures (except area superomedia); propodeal carinae complete, longitudinal carinae relatively weak on apical half. Area basalis trapezoidal, about $0.7 \times$ as long as its basal width. Area superomedia granulate without punctures, $1.4 \times$ as long as its maximum width, its lateral sides weakly convergent apically behind costula, apically opened. 
Costula complete, strong, connected to area superomedia before its middle. Area petiolaris slightly impressed, almost flat, with transverse wrinkles. Fore wing with short-stalked areolet; $3 r s-m$ pigmented; second recurrent vein $(2 m-c u)$ distal to middle of areolet; distal abscissa of $R 1 \mathrm{ca} 1.4 \times$ as long as maximum width of pterostigma; distal abscissa of $R s$ straight; nervulus (cu-a) slightly postfurcal, almost interstitial, weakly curved, about vertical; postnervulus (abscissa of $C u 1$ between $1 m-c u$ and $C u 1 a+C u 1 b$ ) intercepted below middle by $C u 1 a$; lower external angle of second discal cell about right-angled. Hind wing with nervellus $(c u-a+$ abscissa of $C u 1$ between $M$ and $c u-a)$ intercepted at about lower 0.3 of its length, about vertical; discoidella (distal abscissa of $\mathrm{Cu}$ ) complete, connected to nervellus, spectral. Coxae finely granulate to almost smooth with dense, superficial punctures. Hind femur ca $5.3 \times$ as long as high. Inner spur of hind tibia ca $0.5 \times$ as long as first tarsomere of hind tarsus. Tarsal claws longer than arolium, with conspicuously strong, teeth-like pecten almost all along their lengths.

Metasoma: Finely granulate to shagreened with moderately dense to sparse, almost indiscernible superficial punctures, and with short, sparse, whitish hairs. First tergite slender, about $3 \times$ as long as its apical width, $1.15 \times$ as long as second tergite, $0.85 \times$ as long as hind tibia; glymma absent; dorsomedian carina of first tergite indistinct; petiolus smooth, postpetiolus finely granulate; petiolus ca $3.5 \times$ as long as high. Suture separating first tergite from first sternite situated about mid-height at basal third of first metasomal segment. Second tergite $1.4 \times$ as long as its apical width; thyridium oval, its distance from basal margin of tergite about $2 \times$ as long as its length. Epipleurum of second and third tergites separated by a crease. Third tergite little longer than its apical width. Posterior margin of sixth and seventh tergites medially concave, though relatively shallowly excised. Ovipositor sheath as long as hind tibia, ovipositor shaft weakly upcurved, tip acute.

Colour: Apical two-third of antenna blackish to dark brown, apical third reddish brown; scapus and pedicellus entirely blackish to dark brown except apical margins very narrowly yellowish brown. Head black except palpi yellowish brown, and mandible yellowish with blackish base and dark reddish brown teeth. Mesosoma black except tegula yellow. Metasoma black, apical margins of tergites very narrowly, indistinctly brownish; ventral plica reddish yellow; ovipositor sheath black. Wings hyaline, wing veins brown, pterostigma brown. Fore leg: coxa black; trochanter blackish to dark brown, apically very narrowly yellowish brown; trochantellus dark brown, apically very narrowly yellowish brown; femur reddish with apical yellowish spot; tibia reddish, externo-medially yellowish; tarsus reddish, apical tarsomere brownish. Middle leg: coxa black; trochanter black; trochantellus blackish, apically very narrowly yellowish brown; femur blackish to dark brown with apical yellowish spot; tibia reddish, externomedially yellowish, apically brownish; tarsus reddish brown, apical tarsomeres brownish. Hind leg: coxa black; trochanter black; trochantellus black, apically very narrowly brownish; femur almost entirely black, apically very narrowly 
yellowish brown; tibia externo-medially reddish brown, subbasally and apically brown, extreme basal part with a yellowish spot; tarsus brownish.

Male: Unknown.

Distribution - Currently known from Mongolia.

Ecology - No host is known.

Etymology - The specific epithet atrata is the feminine form of the Latin adjective atratus, $-a$, -um meaning darkened, blackened, clothed in black; it refers to the dark colouration of the new species.

Remarks - By using the recently published identification key of the Western Palaearctic species of the genus (VAS 2019d), Ventura atrata sp. n. keys out at couplet 3 together with Venturia atricolor (Györfi, 1946); the distinctive characteristics from this species are given in the Diagnosis section.

\section{Venturia mongolica (Kokujev, 1915)}

Material examined - Mongolia: Suchebaator aimak, Fluss Bajan gol, $85 \mathrm{~km}$ NO von Somon Dariganga, 1100m, 8.VIII.1965, leg. Z. Kaszab (Nr. 377), 1 ㅇ.

Remarks - First record for Mongolia. This species has been known from northern China (Xinjiang) so far (KoKujev 1915, Horstmann 1979, Yu et al. 2012).

Acknowledgements - I am grateful to Dominique Zimmermann and Manuela Vizek (Naturhistorisches Museum Wien), Stefan Schmidt (Zoologische Staatssammlung München), JinKyung Choi (Yeungnam University), and to Marek Wanat (Musem of Natural History, University of Wroclaw) for their help in checking relevant type materials. Thanks are due to Ottó Merkl (HNHM) for his valuable comments on the manuscript, and to Tamás Németh (HNHM) for the photos. The author was supported by the Hungarian Government, Ministry of Human Capacities (Emberi Erőforrások Minisztériuma) in the frame of the NTP-NFTÖ-19-B-0007 scholarship (Nemzet Fiatal Tehetségeiért Ösztöndij).

\section{REFERENCES}

Ashmead W. H. 1906: Descriptions of new Hymenoptera from Japan. - Proceedings of the United States National Museum 30: 169-201. https://doi.org/10.5479/si.00963801.30-1448.169

Au Be RT J. F. 1974: Douze Ichneumonides pétiolées inédites. - Bulletin de la Société Entomologique de Mulhouse 1974(janvier-mars): 1-6.

Barron J. R. \& Walley G. S. 1983: Revision of the Holarctic genus Pyracmon (Hymenoptera: Ichneumonidae). - Canadian Entomologist 115(3): 227-241.

https://doi.org/10.4039/Ent115227-3 
Const antine Anu M. I. \& Mustata G. 1972: Ichneumonides nouveaux (Hym. Ichneum.) dans la faune de la Roumanie. - Revue Roumaine de Biologie (Serie de Zoologie) 17(2): 87-95.

Di Giovanni F. \& Reshchinov A. 2016: Contribution to the knowledge of Ichneumonidae (Hymenoptera) in Italy. - Linzer biologische Beiträge 48(1): 495-505.

Gupta V.K. \& Ma Heshwary S. 1977: Ichneumonologia Orientalis, Part IV. The tribe Porozontini (=Campoplegini) (Hymenoptera: Ichneumonidae). - Oriental Insects Monograph 5: 1-267.

He J., Chen X. X., Fan J. J., Li Q., Liu C. M., Lou X. M., Ma Y., Wang S. F., Wu Y. R., Xu Z. H., XU W. A. \& YAO J. 2004: Hymenopteran insect fauna of Zhejiang. - Science Press, Beijing, $1373 \mathrm{pp}$.

HOPPER H. P. 1959: The pronunciation and derivation of the names of the genera and subgenera of the family Ichneumonidae found in North America north of Mexico. - Proceedings of the Entomological Society of Washington 61: 155-171.

Horstmann K. 1970: Bemerkungen zur Systematik einiger Gattungen der Campopleginae (Hymenoptera, Ichneumonidae). - Nachrichtenblatt der Bayerischen Entomologen 19: 77-84.

Horstmann K. 1978: Bemerkungen zur Systematik einiger Gattungen der Campopleginae. Mitteilungen Münchener Entomologischen Gesellschaft 67[1977]: 65-83.

Horstmann K. 1979: Revision der von Kokujev beschriebenen Campopleginae-Arten (mit Teiltabellen der Gattungen VenturiaSchrottky, Campoletis Förster und Diadegma Förster). Beiträge zur Entomologie 29: 195-199.

Horstmann K. 1980: Revision der europäischen Arten der Gattung Rhimphoctona Förster (Hymenoptera, Ichneumonidae). - Nachrichtenblatt der Bayerischen Entomologen 29: $17-24$.

Horstmann K. 1987: Bemerkungen zur Systematik einiger Gattungen der Campopleginae III (Hymenoptera, Ichneumonidae). - Mitteilungen Münchener Entomologischen Gesellschaft 76: $143-164$.

Horstmann K. 1993: Revision der Gattung Leptoperilissus Schmiedeknecht (Hymenoptera, Ichneumonidae, Campopleginae). - Zeitschrift der Arbeitsgemeinschaft Österreichischer Entomologen 45(3/4): 87-98.

Horstmann K. 2004: Bemerkungen zur Systematik einiger Gattungen der Campopleginae IV (Hymenoptera, Ichneumonidae). - Zeitschrift der Arbeitsgemeinschaft Österreichischer Entomologen 56: 13-35.

Horstmann K. 2008: Neue westpaläarktische Arten der Campopleginae (Hymenoptera: Ichneumonidae). - Zeitschrift der Arbeitsgemeinschaft Österreichischer Entomologen 60: 3-27.

Jonathan J. K. 1999: Hymenoptera: Ichneumonidae. fauna of West Bengal. Part 8. Insecta (Trichoptera, Thysanoptera, Neuroptera, Hymenoptera and Anoplura). - Zoological Survey of India, Calcutta, $442 \mathrm{pp}$.

KASPARYAN D. R. 1981: A guide to the insects of the European part of the USSR. Hymenoptera, Ichneumonidae. 11 Ctenopelmatinae. 12 Phrudinae. 13 Tersilochinae. 14 Cremastinae. 15 Campopleginae. 16 Ophioninae. - Opredeliteli Fauny SSSR 3(3): 316-431. 
Khalaim A. I. \& Kasparyan D. R. 2007: Campopleginae. - In: Lelej A. S. (ed.): Key to the insects of Russia Far East. Vol. IV. Neuropteroidea, Mecoptera, Hymenoptera. Pt. 5. Dalnauka, Vladivostok, pp. 597-632.

KoKujeV N. R. 1915: Ichneumonidea (Hym.) a clarissimis V. J. Roborowski et P. K. Kozlov annis 1894-1895 et 1900-1901 in China, Mongolia et Tibetia lecti 2. - Ezhegodnik Zoologicheskogo Muzeya 19: 535-553.

Kusigemati K. 1972a: Descriptions of three new Ichneumonflies parasitic on Chrysomelid

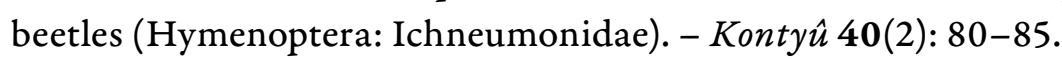

Kusigemati K. 1972b: On the species of Meloboris Holmgren from Japan (Hymenoptera, Ichneumonidae). - Memoirs of the Faculty of Agriculture, Kagoshima University 8: 115-118.

Kusigemati K. 1993: Descriptions of two new Ichneumonflies (Hymenoptera) parasitic on diamondback moth, Plutella xylostella L. (Lepidoptera, Yponomeutidae) from Japan. Japanese Journal of Entomology 61(1): 101-107.

Masnadi-Yazdinejad A., Jussila R. \& Riedel M. 2010: The Iranian fauna of the subfamilies Acaenitinae, Banchinae, Campopleginae, Ophioninae and Tryphoninae (Hymenoptera: Ichneumonidae) with some new records. - Entomologica Fennica 21(2): 70-83. https://doi.org/10.33338/ef.84511

Momoi S. 1962: Descriptions of four Ichneumonidflies parasitic on insect pests of coniferous trees. - Science Reports of the Hyogo University of Agriculture 5(2): 49-52.

Mомог S. 1965: Description of a new Ichneumonfly of the genus Devorgilla from Japan (Hymenoptera: Ichneumonidae). - Science Reports of the Hyogo University of Agriculture $7(1): 38$.

Mомог S. 1970: Ichneumonidae (Hymenoptera) of the Ryukyu Archipelago. - Pacific Insects 12(2): 327-399.

PER KINS J. F. 1942: A note on European Nepiera Förster, with description of a new species (Hym. Ichneumonidae: Ophioninae). - Entomologist 75: 64-65.

RIedel M. 2017: Die westpaläarktischen Arten der Gattung Campoletis Förster (Hymenoptera, Ichneumonidae, Campopleginae). - Spixiana 40(1): 95-137.

ŠEDIVÝ J. 2004: European species of the genus Phobocampe Förster (Hymenoptera: Ichneumonidae). - Acta Universitatis Carolinae Biologica 48(3): 203-235.

Townes H. 1969: The genera of Ichneumonidae. Part 1. - Memoirs of the American Entomological Institute 11: 1-300.

Townes H. 1970: The genera of Ichneumonidae. Part 3. - Memoirs of the American Entomological Institute 13: 1-307.

UchidA T. 1942: Ichneumoniden Mandschukuos aus dem entomologischen Museum der kaiserlichen Hokkaido Universitaet. - Insecta Matsumurana 16: 107-146.

Uchida T. 1957: Ein neuer Schmarotzer der Kartoffelmotte in Japan (Hymenoptera, Ichneumonidae). - Mushi 30: 29-30.

VARGA O. 2017: A review of the genus Rhimphoctona Förster, 1869 (Hymenoptera: Ichneumonidae: Campopleginae) from the Ukrainian Carpathians, with a key to European species. - Zootaxa 4263(2): 387-394. https://doi.org/10.11646/zootaxa.4263.2.12

VAS Z. 2013: First records of three ichneumon wasp species in Hungary (Hymenoptera: Ichneumonidae). - Folia entomologica hungarica 74: 189-194. 
VAs Z. 2015: New records of ichneumon wasps in Hungary, Romania, Serbia and Slovakia with a key to the Western Palaearctic Xylophru rus species (Hymenoptera: Ichneumonidae). - Folia entomologica hungarica 76: 223-240. https://doi.org/10.17112/FoliaEntHung.2015.76.223

VAs Z. 2016a: Woldstedtius merkli sp. n. from Hungary (Hymenoptera: Ichneumonidae). - Folia entomologica hungarica 77: 57-65. https://doi.org/10.17112/FoliaEntHung.2016.77.57

VAs Z. 2016b: New records of wasps in Hungary and Romania (Hymenoptera: Ichneumonidae, Vespidae). - Folia entomologica hungarica 77: 67-78.

https://doi.org/10.17112/FoliaEntHung.2016.77.67

VAS Z. 2016c: Contributions to the knowledge of Ichneumonidae and Gasteruptiidae fauna of Sălaj County, Romania (Hymenoptera). - Studia Universitatis "Vasile Goldiş", Seria Ştiințele Vieții 26(1): 133-140.

VAs Z. 2016d: A new species of Temelucha Förster from Malta with an updated and revised identification key to the Western Palaearctic Temelucha species (Hymenoptera, Ichneumonidae, Cremastinae). - Journal of Hymenoptera Research 48: 67-84. https://doi.org/10.3897/JHR.48.7094

VAs Z. 2016e: Temelucha flavia sp. n. from the southern Mediterranean region (Hymenoptera: Ichneumonidae: Cremastinae). - Ecologica Montenegrina 8: 38-44.

VAS Z. 2018: New species and new records of ichneumon wasps from Hungary and adjacent countries (Hymenoptera: Ichneumonidae). - Folia entomologica hungarica 79: 81-100.

VAs Z. 2019a: Contributions to the taxonomy, identification, and biogeography of the Western Palaearctic species of Campoletis Förster (Ichneumonidae: Campopleginae). - Zootaxa 4565(3): 373-382. https://doi.org/10.11646/zootaxa.4565.3.4

VAs Z. 2019b: New species and new records of ichneumon wasps from the Eastern Mediterranean and the Black Sea regions (Hymenoptera: Ichneumonidae). - Acta Zoologica Academiae Scientiarum Hungaricae 65(1): 19-30. https://doi.org/10.17109/AZH.65.1.19.2019

VAs Z. 2019c: Contributions to the taxonomy, identification, and biogeography of Eriborus Förster, 1869 and Nepiesta Förster, 1869 (Hymenoptera: Ichneumonidae: Campopleginae). Opuscula Zoologica Instituti Zoosystematici et Oecologici Universitatis Budapestinensis 50(1): 87-98. https://doi.org/10.18348/opzool.2019.1.87

VAS Z. 2019d: Contributions to the taxonomy, identification, and biogeography of Casinaria Holmgren and Venturia Schrottky (Hymenoptera: Ichneumonidae: Campopleginae). Zootaxa 4664(3): 351-364. https://doi.org/10.11646/zootaxa.4664.3.3

VAs Z. \& KutAsi Cs. 2016: Hymenoptera from caves of Bakony Mountains, Hungary an overlooked taxon in hypogean research. - Subterranean Biology 19: 31-39. https://doi.org/10.3897/subtbiol.19.10016

VAs Z., Mifsud D. \& BROAD G. R. 2015: New records of ichneumon wasps (Hymenoptera: Ichneumonidae) from Malta. - Bulletin of the Entomological Society of Malta 7: 139-142.

VAS Z. \& SCHWARZ M. 2018: Contributions to the taxonomy, identification, and biogeography of Thaumatogelis Schwarz, 1995 (Hymenoptera: Ichneumonidae). - Zootaxa 4444(4): 421-436. https://doi.org/10.11646/zootaxa.4444.4.4

Yu D. S. \& Horstmann K. 1997: A catalogue of world Ichneumonidae (Hymenoptera). - The American Entomological Institute, Gainesville, 1558 pp. 
Yu D. S., van Achterberg C. \& Horstmann K. 2012: Taxapad 2012, Ichneumonoidea 2011. Database on flash-drive. www.taxapad.com, Ottawa, Ontario, Canada.

ZILAHI-KIssE. 1924: Beitrag zur Kenntnis der ungarischen und siebenbürgischen Ichneumoniden(Schlupfwespen-) Fauna. - Verhandlungen und Mitteilungen des Siebenburgischen Vereins für Naturwissenschaften in Hermannstadt 72-74: 32-146.

Zilahi-Kiss E. 1926: Zweiter Beitrag zur Kenntnis der ungarischen und siebenbürgischen Ichneumoniden- (Schlupfwespen-) Fauna. - Verhandlungen und Mitteilungen des Siebenburgischen Vereins für Naturwissenschaften in Hermannstadt 75-76: 74-120.

Zilahi-Kiss E. 1933: Vierter Beitrag zur Kenntnis der ungarischen und siebenbürgischen Ichneumoniden-(Schlupfwespen-) Fauna. - Verhandlungen und Mitteilungen des Siebenbürgischen Vereins für Naturwissenschaften in Hermannstadt 81-82: 43-65. 